\title{
INVESTIGATING ENGLISH NEED OF SHARIA BANK EMPLOYEES IN PAREPARE SOUTH SULAWESI
}

\author{
Zulfah \\ Da'wah and Communication Department, IAIN Parepare \\ fakhruddin.zulfah@yahoo.com \\ Mujahidah \\ Tarbiyah Department, IAIN Parepare \\ idhasuher@gmail.com
}

\begin{abstract}
This study was aimed to investigate English need of sharia bank employees in Parepare. The design research was qualitative research. Subject of the research was 12 employees in 3 sharia banks in Parepare. Research data was collected by using interview. The findings showed that: (1) Islamic bank employees need English materials relate to banking, accounting, and computer application; and (2) Islamic bank employees need reading skills more than listening, speaking, and writing skills because they work more with English written documents. Bank employees also work with computer program. All instructions and terms in computer are in English. The employees need good pronunciation in English term of banking, accounting, and computer. They also need skills in correspondence in electronic letter or email.
\end{abstract}

Key words: English need, English materials, and sharia bank employees.

\section{A. INTRODUCTION}

ank employees have to deal with communication of lots of important policies and
procedures to their clients. The policies and procedures consist terms and concepts in
English that can be difficult to comprehend. However, English skills are necessity for sharia bank employees to support their job. Salameh and Olfat (2015) found out an urgent need for English in dealing with foreign customers, understanding new electronic administration requirements, and dealing with English documents and endorsements and getting use of foreign experience in developing banks' work. Mohammdzadeh, Barati \& Fatemi (2015) also stated that nowadays, banks are moving toward electronic world therefore bank employees need to know English if they want to improve their products and compete with other banks.

The necessity of English skills for bank employees is considered by bank employees can support their job however they also considered that their English ability is low. Mohammdzadeh, Barati \& Fatemi (2015) reported that bank employees of Saderat bank in Mashhad considered all four English skills (listening, speaking, reading, and writing) were very difficult for them. Chew (2005) reported that the sources of difficulty of bank employees in carrying out their work tasks 
were financial content and language demand. All written input and output are in English. The stem of their writing difficulty is from the use of English. Then, other bank employees must work with English extensively because in addition to the customary banking practice of writing memos and reports in English. They also have to translate oral information in native language into English.

Analyzing English need of sharia bank employees become important to be conducted to prepare English training for them. The data of analysis also can be input to design English curriculum and teaching materials for students at sharia economy and accounting study program. In 2012, Adewumi \& Owoyemi found that bank employees' English needs are different based on their role, functions, and responsibilities. Then, Wijewardene et al (2014) stated that it is necessary to create a market-driven tertiary Education system which incorporates need analysis and thereby empowers graduate to be work-ready and uplift his/her organization in the business environment. The ability to communicate effectively in English plays a pivotal role in assessing of the suitability of graduates for gainful employment.

In this study, the researcher administered two research questions: (1) what English materials do sharia bank employees need to support their job? and (2) what English skills do sharia bank employees need to support their job?

\section{B. REVIEW LITERATURE}

\section{English for Employability}

Today, English is considered as being the language of the world due to it wide acceptance as being the vehicle of communication that can transcend all barriers, and learning the language and being fluent in it, especially for those on the threshold of employment is a necessity. Fitzpatrick \& O'Dowd (2012) stated that it is becoming more and more common to find English as a foreign language programs being refocused to enable learners not only to develop their English proficiency, but also to learn how to master and integrate other competences such as digital competence and cultural awareness, into their repertoire of skills.

Being knowledgeable and fluent in English is undoubtedly a powerful tool that can bring about personal as well as global advancement and development. A good English language proficiency amongst graduates enhances their employability and is a gateway to the world of work-readiness which will attract the attention of prospective employers (Wijewardene et al: 158 
2014). In same line, Chew (2005) stated that the importance of English in gathering information from written sources such as research report, brokers' reports, Bloomberg Financial Services and other such sources needs to be understood. When the research content is international nature or deals with international companies, the reading materials are in English.

\section{English for Banking}

English has been elevated to the position of a common corporate language in order to bring about an economic integration and a closer networking in the global business environment (Wijewardene et al: 2014). With the increase in marketing and trading, recognition of the need for improved English communication skills has been growing among banking professionals. Bank employees will need to know English if they want to improve their products and compete with other banks. In order to keep their knowledge of banking profession up to date, bank employees should study the recent books and magazines about financial trading. Nowadays banks are moving toward electronic world and it makes knowing English necessary (Mohammadzadeh, Barati, \& Fatemi: 2015).

\section{English Training for Employees}

Wijewardene et al (2014) stated that skills such as computer skills, experience/training, leadership and decision-making skills, team work and interpersonal skills, and problem solving and analytical skill, and communication skills in English are important to graduate to display work-readiness. The ability to communicate effectively in English plays a pivotal role in assessing of the suitability of graduates for gainful employment. Thus, the onus is on institutions of tertiary education to focus on this significant and the vital attribute in their course curriculum so as to release into the job market graduates who are employable and are able to communicate in a way suitable to the graduate's discipline, the audience and the purpose. Considering the importance of English skills for bank employees, useful English language instruction is highly necessary to be conducted to prepare the bank employees to do job effectively.

Chew (2005) stated that the employees' interest in receiving language training is somewhat stronger for speaking skills than writing skills. For speaking skills, they are interested in receiving training in presentation skills, oral English for daily use and social interaction, negotiation skills and business conversations. For writing skills, the employees are interested in learning to write reports, business letters, minutes, and bank documents. She also found several reasons for the 
bank employees' stronger interest in speaking skills. The first reason, the new bank employees may be carrying interest in having more oral English training. The second reason is the limited opportunity and need to speak in English with their colleagues in the workplace. Hence, when they think or improving their English, they tend to think of getting more time and opportunity to talk in English, something that they rarely do outside the classroom setting. The third reason is duration. It sometimes seems that quicker results are possible in speaking than in writing and learners may want the gratification of seeing more immediate results within a shorter training period than in working slowly towards making more modest progress in writing skills over a longer training period.

Considering the importance of English for business, Bathia and Bremner (2012) developed EBP (English for Business Purpose) Program. The syllabus of EBP program provide (1) intensive course that would be helpful to the students in their working lives, (2) a communicative course on which students could adapt their current general English knowledge for use in business situations, (3) a course that took into consideration cultural issues when communicating with foreign business people, and (3) realistic (authentic) examples of language.

\section{RESEARCH METHOD}

The researchers used qualitative research for the purpose of the study. The subject of the research was 12 employees in 3 sharia banks in Parepare, South Sulawesi. The banks were Muamalat bank, sharia Mandiri bank, and BMT Faudzan Adzima.

The researchers used interview to collect data. The interview consists of some questions relate to English materials and skills that employees need to support their job. Data analysis consists of some steps: reading/memoing data, categorizing/coding data, organizing and interpreting data.

\section{FINDINGS AND DISCUSSIONS}

\section{Analysis of English Materials of Sharia Bank Employees}

The analysis of interview data showed that sharia bank employees need English materials relate to: (1) banking and accounting and (2) computer program.

Interview data was administered below: 
Volume 4, Number 2, December 2018

"Biasanya kami hanya menggunakan bahasa inggris untuk istilah-istilah perbankan atau akuntansi. Biasa juga untuk program komputer. Biasanya kan komputer itu pakai istilah-istilah bahasa inggris". (Translation: "We usually work with English for banking and accounting terms. We also work with English for computer program. Generally, computer program consists of terms in English").

The other interview data is below:

"Paling ituji, kita biasa gunakan istilah-istilah perbankan, akuntansi atau komputer". (Translation: "We use English for terms of banking, accounting, and computer").

Banking and accounting terms are almost in English. The terms relates to not only bank activity, for example payment, fund, tax, money investment, loan, insurance, etc but also profession, for example teller, customer service, manager, etc. Accounting relates to company's balance sheet or bookkeeping. Leiwy (2015) states that the earliest roles of accounting information were to measure and record financial transaction and provide information for stewardship purposes. Accounting terms in English are for example assets, balance sheet, capital, cash flow, etc.

A computer is a programmable machine. It allows the user to store all sorts of information and then 'process' that information, or data, or carry out actions with the information, such as calculating numbers or organizing words (Roper, 1999). Salameh and Jarad (2015: 43) find out that English has relationship to modern electronic administration requirements. It is because: (1) English is a key for global communication through various modern technology means, (2) English is vital communication tool between the bank and the foreign society, (3) means and tool of modern electronic technology needs English language skills, (4) English is widespread through the internet and other electronic shopping websites, (5) English through electronic tools meet with globalization, (6) modern office tools require good English, (7) good use of English through electronic programs is important for communicating with customers, (8) majority or computerized programs at the bank they work in are prepared in English, and (9) English is vital communication tool between the customer and the bank.

Knowledge about banking, accounting, and computer plays an important role for Islamic economy students to support them in job selection and work in finance office. However, banking terms, accounting terms, and computer applications are full of terms and concepts that can be difficult to comprehend. Chew (2005) reported that banks employees in Hong Kong cite financial or banking content as their source difficulties to carry out their various tasks. Gaye (2015) also 
reported that among the $74 \%$ of bank or post-office workers face difficulties communicating in their jobs. This situation is due to a lack of adequate vocabulary. Indeed, they do not find the appropriate terms needed to effectively express themselves. Then, Salameh and Olfat (2015) reported that the relationship between English language and modern electronic administration requirements is highly developed and appreciated and well rewarded by Palestinian banks employees despite the Arabization of software's used at their niches as most programs and software's are originally English, which requires employees to be qualified users of English in order to deal with those software's and electronic administration tools and aids as well. Therefore, English vocabulary relates to banking, accounting, and computer should be taught to Islamic economy students to support them to success in their study and career.

\section{Analysis of English Skills of Sharia Bank Employees}

The need priority of English skill relates to Islamic economy and banking is arranged from reading skill, speaking skill, listening skill, and then writing skill.

Reading skill. Bank employers work with written documents. Most of documents contain banking and accounting terms written in English. They need English reading skill to understand the documents. Bank employers also work with computers. All instructions and terms in computer are in English.

Speaking skill. The need of bank employers toward speaking skill is in pronunciation area. They must be able to pronounce well English accounting and banking terms, especially pronunciation of profession in bank.

Listening skill. Listening materials of English teaching for Islamic economy students is similar to speaking materials. They are accounting terms, banking terms, and profession in bank.

Writing skill. Writing materials includes banking correspondence. The correspondence is conducted in electronic letter or email.

The findings show that bank employers need English reading skill more to support their jobs. Speaking, listening, and writing skills are less useful for them because their customers are native Indonesian people, and their colleges are too. They do communications by using Indonesian language. The interview data is administered below:

"Kalau skill yang paling kita butubkan di bank itu adalab reading. Kenapa, karena kitakan banyak membaca dokumen-dokumen dan istilah-istilah dalam dokumen itu biasanya bahasa inggris. Kalau pakai komputer itu kan instruksinya itu dalam bahasa inggris, jadi kalau tidak tau bahasa inggris yah susah 
Volume 4, Number 2, December 2018

mengoperasikan computer." (Translation: "The skill we need most in bank is reading. Why? Because we need to read documents then the terms in documents are in English. All instructions in computers are in English. If we don't know English, we will find difficulties in operating the computer").

The interview related to speaking skill is below:

"Kalau untuk bercakap bahasa Inggris, ai, tidak pernah karna customer juga rata-rata orang bugisji. Biasaji kita pakai bahasa inggris untuk sebutkanki itu istilah-istilah perbankan atau panggilan sesama kita krn kan nama-nama job itu di kantor sudah berbahasa inggrismi seperti office boy, manager." (Translation: "Speaking English, we seldom do it because most of our customers are Buginese. We usually use English to say banking terms and to call each other because the job positions in this office is in English such as office boy, manager, etc.").

The interview related to writing skill is below:

"Menulis? Ai.... jarang, paling juga kalau mau menulis surat atau email tapi itupun biasanya hanya terbatas pada istilah-istilah perbankan atau akuntansi." (Translation: "Writing?... seldom. We use English only for writing letter or email but it is only for banking or accounting terms").

The interview related to listening is below:

"Kalau listening, tidak pernah. Paling ituji kak kalau kita dengar panggilan teman-teman atau istilah tempat di kantor seperti pantries atau cleaning service atau teller. Begituji kak." (Translation: "Listening, never. We only listen English when call eact other or name of places in office such as pantries or cleaning services or teller').

The findings are same line to Chew' findings. She (2005) reported that almost all written communicative tasks are carried out in English while most oral communicative tasks are carried out in Cantonese, the language of the majority of people in Hong Kong. Then to sum up, much of the reading and almost all of the writing are done in English while the oral activities and tasks are conducted in Cantonese unless the oral communications is with non-Chinese participants. The communication skills are fundamental to success in work. Ability to communicate verbally and written is important skill for any job. Finance professionals have to deal with the communication of lots of important policies and procedures to their clients. They have to address the budgetary concerns of the management along with redresses of customer complaints for which they should have the required communication skills. There are a number of banking positions that require one to communicate with customers on a regular basis, answering their queries. Meetings, presentations, and conferences are an important part of most managerial roles in these sectors, which again require the candidate to have excellent communication skills. 
Communication skills include English language skills. Gaye (2015: 10) found that almost all the business professional (87\%) need or use English in their jobs. Bank employees will need to know English if they want to improve their products and compete with other banks. In order to keep their knowledge of banking professions up to date, bank employees should study the recent books and magazines about financial trading. Nowadays banks are moving toward electronic world and it makes knowing English necessary. With the increasing in marketing and trading, recognition of the need for improved English communication skill has been growing among Banking professionals. In other words, useful English language instruction is highly necessary to do the job effectively (Mohammadzadeh, Barati, \& Fatemi, 2015).

\section{E. CONCLUSION}

In this article, researchers draw two conclusions: the first is English teaching materials for Islamic economy students include two main topics. They are banking and accounting terms and computer application. Banking and accounting terms relates to not only bank activity, for example payment, fund, tax, money investment, loan, and insurance but also profession, for example teller, customer service, and manager. Computer application relates to computer program that allows the user to store all sorts of information or data or carry out actions with the information, such as calculating numbers or organizing words. The second is the need priority of English skills relates to Islamic economy and banking is arranged from reading skill, speaking skill, listening skill, and then writing skill. The findings show that the bank employers needs more English reading skill than other skills to support their job. Speaking, listening, and writing are less useful for them because their customers are native Indonesian language.

\section{REFERENCES}

Adewumi, O. F., \& Owoyemi, A. O. (2012). The Relevance of English Language Syllabus for Commercial Bank Workers in Nigeria: An Empirical Study. American International Journal of Contemporary Research, 105-112

Bhatia, V.K., \& Bremner, S. (2012). English for Business Communication. Language Teaching, 410445.

Chew, K.S. (2005). An Investigation of the English Language Skills Used by New Entrants in Banks in Hong Kong. English for Specific Purposes, 423-435. 
Volume 4, Number 2, December 2018

Fitzpatrick, A. \& O’Dowd, R. (2012). English at Work: An Analysis of Case Reports about English Language Training for the 21th Century Workforce. USA: The International Research Foundation for English Language Education

Gaye, A. (2015). “Assessing English Language Needs of the Senegalese Professional Working in Business and Tourism Sectors in Saint-Louse Senegal”. International Journal of English Language and Translation Studies, 1-15.

Leiwy, D. (2015). Principle of Accounting. UK: University of London.

Mohammadzadeh, S., Barati, T., \& Fatemi, M. A. (2015). An Investigation into the English Language Needs of Bank Employees of Saderat Bank in Mashad. Theory and Practice in Language Studies, 1695-1702.

Roper, M. (1999). Understanding Computers: an Averview for Records and Archieves Staff. UK: International Records Management Trust.

Salameh, S. M., \& Jarad, A. O. (2015). Banks' Employees' Attitudes towards the Role of English Language in Banks' Work: A Case Study of the Commercial Banks Operating in Tulkarm/Palestine. Global Journal of Human Resources Management, 19-44

Wijewardene, L., Yong, D., \& Chinna, K. (2014). English for Employability - the Need of the Hour for Sri Lankan Graduates. British Journal or Arts and Social Sciences, 137-145. 